\title{
PROGRAM EVALUATION TOWARD MILLENNIUM DEVELOPMENT GOALS IN EDUCATION ASPECT AT KUNINGAN REGENCY WEST JAVA
}

\author{
Iman Subasman \\ STAI AL Ihya Kuningan \\ imansubasman@gmail.com
}

\begin{abstract}
The purpose of this evaluation is to find out the effectiveness of implementing the Millennium Development Goals (MDGs) in education aspect at Kuningan Regency, West Java. Evaluation models that is used are Context, Input, Process and Product (CIPP). Data were obtained through interviews, questionnaires and documents. The results of the evaluation on the aspects: (1) context, local governments follow up with local policies, (2) inputs, the implementation of the guidelines does not have a strong force of law, (3) process, increasing the access to school for the people's, and (4) product, increasing enrollment in primary education. Increasing effectiveness can be done with a stronger regional policies, monitoring, coordination of bureaucratic structure, socializing the concept of MDGs to executor and developing people perception on education.
\end{abstract}

Keywords: MDGs, CIPP, enrollment in primary education.

For the common interest in promoting development in developing countries, as many as 189 countries made a joint commitment in development (BAPPENAS, 2008: 1). These countries made commitments of common interest in promoting development in developing countries. This commitment is expressed in a global development concept with the name of the Millennium Development Goals (MDGs).

MDGs focus is human development as a real welfare thing creation and improvement of life. In the focus of development, MDGs programs prioritize development that can improve human development index (Human Development Index) or HDI. The three main sectors of human development as defined by the government is the development of education, economy and health. Three sectors are taken as the main factor to improve the welfare of the community. Economic development aims to increase purchasing power, health development to reduce the death rate and increasing life expectancy, as well as the development of education to provide educational services to the entire population and improve the knowledge and learning opportunities evenly.

Achievement Indicators of the MDGs in education is (Net Enrollment Ratio (NER)), the (Gross Enrollment Ratio (GER)) Primary School and Junior High School reach $100 \%$ in 2015. With the indicator means the situation of children of primary school age and junior high schools throughout the region on 2015 has finished school until junior high. To achieve this target the governments provide equal opportunities to children aged 7-15 years old to finish the 9 years of basic education.

Currently education is facing some challenges, such as: (1) the high dropout rates, (2) the educational gap between groups and (3) the capacity gap. Of the challenges faced by the government through the MDGs to make efforts in order to create educational equity in society. By experiencing good 
educational services is expected to have an impact on the improvement of human resources in the future. To achieve these expectations the government has made some efforts of development: (1) increase the relevance of education and (2) increase the efficiency and utilization of evaluating educational resources. These circumstances make the central government to implement local development-oriented achievement of the MDGs. To realize the MDGs target of the government to provide support through policy, funding and evaluation periodically. Efforts by the policy embodied in the form of regulations including laws, regulations and president's instructions.

The government effort is followed-up by the provincial government to conduct an evaluation, make regulations provincial level, making implementation and evaluation guidelines on MDGs to the local (Regency/ City). This situation shows that MDGs program involves structural governance from the central to local levels.

The pattern of structural evaluation of the central government to the regions will require structural pattern of government coordination, communication, sufficient resources and a clear disposition. With this state of MDGs as a policy requires the factors that can support its success. To achieve its success of the policies it is needed four things to support the successful implementation of policies that is, bureaucratic structure, communications, resources and disposition (Edward III: 1980: 10).

Evaluation is needed to provide recommendations and improvements the MDGs programs in the future. Recommended improvements will provide benefits to the achievement of MDGs program. The right evaluation will provide an opportunity for evaluators to collect data, information and accurate analysis and provide recommendations to the achievement of the MDGs program. Characteristics of Context, Input, Process and Product (CIPP). CIPP is located on making provisions to holistically evaluate which elements of the system-oriented, structured to accommodate the needs of the universal evaluation (Hsing Kuo: 2012: 250-259). CIPP can be used to conduct formative and summative evaluation (Tiantong: 2013: 157-165).

Recommendations can be an improvement from several sides including the pattern structural relationship bureaucracy in implementing the MDGs, an improvement on the resources (funds and human resources), improved communication between program managers and coordination among the MDGs implementers at the same level or at different structural levels. For the model of a more comprehensive evaluation is necessary to improve the achievement of the MDG targets.

Considering the characteristics of the MDGs program, there are two important aspects namely policy and pattern of the relationship between bureaucratic structure. The policy question is the existence of government regulations that are directly related to the MDGs. After the government issued a policy, it has an implications that such of policies should be implemented to the level of local government. To achieve the target of policy implementation, there are several factors that can determine the policy implementation. These factors have a mutual relationship, it is bureaucratic structures, resources, socialization programs and coordination and disposition. This situation provides an understanding that the implementation 
of policy analysis in evaluating the MDGs program becomes very necessary. In addition to requiring the analysis of policy implementation, to see the progress of MDGs program it is required an evaluation model that gives a comprehensive overview and complete evaluation has been carried out. Evaluation model that the researchers consider appropriate to provide a comprehensive overview is CIPP evaluation model (Kuo-Hung Tseng: 2010: 256). Four components of CIPP can provide a comprehensive overview of the implementation of MDGs.

Based on the above evaluation aims to determine the effectiveness of MDGs programs and special education evaluation aims to determine the implementation of MDGs from the aspect of context, input, process and product. Context evaluation is to determine the targets, legal basis and follow-up of government policies, requirements analysis, the adequacy of the terms of the implementation of the MDGs in education programs and program goals. In the aspect of the Input evaluation is needed to determine the planning, financing, guideline implementation, adequacy of infrastructure and human resources prepared to carry out the program and support infrastructure provided. In the aspect of the process evaluation was conducted to determine the implementation of activities that support the achievement of the MDGs in education, implementation of monitoring, disposition, and bureaucratic support which is given to implementing activities and implementing response activities. In the aspect of the results

Evaluation was conducted to determine the target achievement of the Gross Enrollment Ratio (GER) Primary School and Junior High School and net enrollment ratio (NER) Primary School and Junior High School.

\section{THEORETICAL STUDY}

Program evaluation is the systematic collection of data for the assessment and the decision of the program (Patton: 1997: 23). From the formula, there are three important things to evaluate that data collection, assessment and decision making. It is important to capture the data that the data collection should be carried out systematically in accordance with the evaluation design (Dale: 2004: 44). It can be interpreted that the data collection should have a plan in order to obtain the correct data. Systematic retrieval of data has an idea that should be adapted to the stages and procedures established in the planning process evaluation. Systematic retrieval of data that will give a true conception of the implementation of the program.

After a systematic process of data collection, the evaluation was followed-up by assessment. Assessment is done based on the facts obtained and granting criteria on objects (Djaali; 2008: 1). The assessment can be done by comparing the results of the achievement of the program with the goals set in program planning. The same thing was raised by Rutman that program evaluation is used to measure the extent to which program objectives achieved (Leonard: 1980: 19). Results of the assessment is then used as the basis for determining decisions. As stated by Mizikaci that 
evaluation is a systematic step through data collection to give consideration and decision (Mizikazi: 2006: 41).

The intended decision is a decision making for the program. The decision is made to repairs programs and policies that will come. (Patton: 1997). Thus the purpose of the evaluation is to improve policies and programs in the next period. This concurs with Spaulding who argued that evaluation is done for the purposes of decision making, determining the assessment of the program and make a recommendation (Mizikazi: 2006: 5). Of opinions that have been expressed can be understood that the program evaluation activities systematically collecting data, assessing a program and make a decision and recommendations for improvements to policies and programs that will come.

Rosye suggested program evaluation as a management tool that can be used for decision-making and improve the social services (Royse: 2006: 11). As a management tool gives the sense that the evaluation as part of the management components, namely planning, actuating, organizing and controlling (Royse: 2006: 6). Being part of the management function evaluation can serve as a control for the implementation of programs and management functions. In addition to relating to management functions, more specifically Rosye argue evaluation role in improving social services. This gives an understanding that the evaluation will have an impact on the quality of social services. Of the concepts it is understandable that the evaluation is a social research activities.

The linkage between social research and evaluation of programs proposed by Freeman that program evaluation is the application of social research procedures to assess the concept, design, implementation and usefulness of the program (Rossi: 1985: 19). Evaluation is not only assess the implementation and achievements of the program but more comprehensively evaluating program design and usefulness. Of the opinions expressed by Rosye and Freeman we can understand that the evaluation can be used to provide assessments and decisions to the concept, design and quality of social services. Thus the evaluation can provide recommendations for improvements to the concept, design and implementation of social programs in the future. In addition to improve, the recommendations of the evaluation are able to the efficiency and effectiveness of the program (Leonard: 1980: 18).

Concept evaluation Demarteu quoting the opinion expressed Barbier that evaluation is a value judgment (Demarteu: 2002: 457). Consideration of the value in question is the result of the evaluation carried out has the legality and validity. Demarteu suggests three important points in the process evaluationthey are process, product and usability. Referring to Rosye opinion, the evaluation is useful for the program of a community. In the implementation, evaluation should assess how much useful program conducted for the public.

Besides Barbier, Demarteu Nevo quoted the opinion that gives the sense that the program evaluation is a systematic investigation to measure the achievement of the program through the collection of information to make a decision (Demarteu: 2002: 458). With this opinion, it is 
understandable that the collection of information must complete and indepth. The data obtained should reflect the overall project activities including planning, processes, results and usefulness to the community. The collected data should be valid and legal by comparing the evaluation data with the expected state (Anselm: 1990: 46). The results of the analysis is the basis for understanding the facts that exist and as experience for the implementation of the next program (Patton: 1997: 154). Understanding the facts can be interpreted in mapping the frame of mind and try to make the relationship between the actual facts of the success obtained (Parson: 2008: 159).

From the descriptions we understand that the process of systematically collecting data to provide an assessment of the results of a program and make recommendations is to increase the value to the community on the implementation of the next program. Perspective on the Result Evaluations can lead to differences in perception between the evaluator with the public, it is necessary to make adjustments to the perception of success as perceived by the evaluator with perception by the public. This was done so that the next policy can be understood as an attempt to repair the program in the community and no different perceptions of the success of a program (Yahaya: 2001: 3).

From the definition we can interprete that one measure of program assessment is perceived by the public benefit. The size of the benefits perceived by the public to be strongly associated with government policy. As Dunn argued about the concept of evaluation can be used to estimate (appraisal), gives figures and assessment (assessment) of the policies relating to the public. Evaluation with regard to the production of information concerning the value of the benefits of the policy (Dunn: 2001: 608).

Understanding Dunn can be a complement to the concept of program evaluation. Program evaluation can deepen the information on the implementation of policies that form the basis of the implementation of the program. Deepening information about policy implementation can be done by knowing the factors that support the implementation of the policy as in effect policy implementation is the way that the policy should achieve the expected goals (Nugroho: 2004: 158). To achieve the expected goals of government may issue policies that are considered in accordance with the authority.

Edward III argued that in order to conduct an evaluation of policy matters that must be considered is the bureaucratic structure, resources, communication and disposition (Edward III: 1980: 12). Bureaucratic structure has an important role in the implementation of the policy. Bureaucratic structure in question is a person and structure. Implementation also requires considerable resources. Achievement programs and policies should be tailored to the available resources. Another thing that can be understood from Edward III is a behavioral pattern and policy implementers, namely communication and disposition. Communication gives an important role to understand the goals and targets of a policy and how to implement them and make a disposition. Why an authorize executes to achieve the targets set. To perform some elements of policy evaluation we must consider 
about: 1) counting and 2) comparing of impacts and targets and 3) efficiency and contribute to improve the subsequent decision (Weis: 1972: 115).

In conducting the evaluation, the evaluators are not just waiting for the information but he actively make plans to obtain information (Guba: 1983: 14). Evaluators must be enabled to communicate with stakeholders (Owen: 2006: 48). so that the information can provide an overview needed for decision-making and policy. This situation illustrates that the programs and policies underlying both have very close relationships and complementary. Program evaluation can be complemented with an analysis of policy and vice versa (Mizikazi: 338).

From the above set can be concluded the similarity between the concept of program evaluation and policy evaluation. Both of these concepts have in common of the data collection in process, assessment, make decisions and recommendations. Policy evaluation stressed to how efforts in achieving the objectives of policy executors and program evaluation focuses on how to input, process and output of a program. Policies and programs both have relevances. The basis of policy and program implementation is the implementation of the policy.

From the description above we can conclude that the program evaluation is a systematic process of searching and analyzing the facts to compare the achievement of the program on the aspects of context, input, process, and products with the criteria established to provide assessment, decision and recommendation. The concept of the study will serve as a guide in conducting research in MDGs' education.

Selection of an appropriate model to evaluate the program carried out in accordance with the characteristics of the program. MDGs education programs have such character in a policy so that the foundation of development policy, budgetary policies and local governments (provincial and district / city), requires the support of adequate resources, the involvement of the bureaucratic structure relationships. Involvement in the process of bureaucratic relationship MDGs is a typical characteristic for the implementation of the MDGs program involving the government bureaucracy with local government and the linkages between local government unit. Suit the characteristics of the evaluation model that can describe most of the characters MDGs is CIPP of modal evaluation. CIPP stands for context, input, process and product. CIPP try to describe the whole range of activities from the outset to those activities produce or achieve the targets that have been set (Stufflebeam: 1894: 151). Originally CIPP done in the field of education, but eventually this evaluation model has been widely used to evaluate other areas such as training and some researches so it makes the basic model for combining models of evaluation in an effort to enhance the evaluation. CIPP model is also regarded as a comprehensive evaluation model that can be used to evaluate programs, personal and organizational evaluation (Zhang, 2011: 57). CIPP evaluation model may be used to conduct formative evaluation and summative evaluation (Tiantong: 2013: 157). Formative evaluation is an evaluation conducted during the program while summative evaluation is an evaluation conducted at the end of the program. Context evaluation, input evaluation and evaluation process 
including formative evaluation categories while product evaluation is summative evaluation that reveals about the quality, utility and value in a program. Characteristics of CIPP located on making provisions to holistically evaluate which elements are systems and structured to accommodate the needs of the universal evaluation (Kuo: 2012: 250). Noting form CIPP activities can also be used to perform internal and external evaluation. Internal evaluation conducted by evaluators of the implementation of the program while the external evaluation conducted evaluators from outside the program. CIPP evaluation model to evaluate the four components, namely the evaluation context, input evaluation, process evaluation and product evaluation. These four components are then used as a guide in understanding the procedures and objectives of the program in detail (Stufflebeam: 1988: 28). Then the Result Evaluations obtained are used to measure the success of the program, support the preparation of plans and improve the next program (Sudjiono: 1996: 8).

\section{Context Evaluation}

Context evaluation is to understand the background of a context of the program and the initial conditions of a program. Evaluation of the context is the basis of the evaluation aims to provide reasons in determining the destination so in the context of the evaluation an evaluator will provide an overview, details of the characteristics of the program, the needs of the program goals and objectives. The main objective in the context of the evaluation is to identify the environment in order to achieve the mission and program objectives (Azizi: 2001: 16). Such identification is to measure, interpret and investigate the progress of the program so that the results obtained an indicator to improve existing mission. It is done by analyzing the context of planning, goals, objectives and priority activities (Tan: 2012). Goal setting is a very basic thing of a program. Goal setting includes general purpose and special purpose. Goal setting is done by assessing the needs, problems, assets and opportunities that are relevant to the program (Fyrye: 2012: 288). The existence of destination will allow your program to achieve the targets that have been set. From the beginning of the program we set our goals and have a clear direction so that the implementation of the program is always oriented to the intended purpose. In its efforts to achieve the goal, a program will perform the activities. It is necessary for the determination of prior activities to be carried out and assess needs to get an idea of the gap between the actual situation with the desired ideal state.

In the context of the evaluation of setting goals, objectives and priorities of the activities carried out by looking at planning. Good planning will consider these three components before the program is implemented. Planning an activity image start to finish activities (Kuo: 2012: 250). The purpose of planning is to identify the needs that are required to fit the objectives of the program will be evaluated. Therefore, in the context of the evaluation, planning is done by identifying the needs, opportunities and problems that may occur in the implementation of the program (Boulmetis: 2013: 1). After the identifications will be illustrated potential opportunities 
and problems faced in order to carry out planning in accordance with the objectives of the program which will be evaluated.

Evaluation context also conducted with respect to the analysis of the weaknesses and strengths of the program. Knowledge of weakness that the implementation of programs that can be done to anticipate the weaknesses that have been predicted from the beginning and understand the advantages that the implementation of the program can be utilized to increase the surplus product and cover weaknesses. With knowledge of the weaknesses and strengths of the evaluator we can provide the necessary improvements. One important thing to look at the advantages and disadvantages is to look at the financial planning and financial efficiency.

In addition to goals, objectives, priority activities, planning, analysis of the advantages and disadvantages of evaluation context also makes evaluation of policy or legal basis used to perform activities. The legal basis is the legality of the execution of a program. On the legality of a program of government activity is obtained by issuing government policies which are then used as a reference in the implementation of the program. A policy which became the basis of the implementation of the program as well as a resource based to provide in supporting the programs carried out. Then the evaluation focused on the evaluation context of planning, evaluation objectives, evaluation objectives, policy evaluation, evaluation of the advantages and disadvantages of the program and needs analysis. In case of government programs that need to be taken into consideration in the evaluation context is an analysis of the policy that underlies the implementation of the program (Tseng: 2010: 10).

Based on the above descriptions can be concluded evaluation is an evaluation to assess the context in a way to evaluate the policy, legal basis, needs analysis, feasibility studies and program goals. In the context of the evaluation of the MDGs evaluation is done by evaluating legal basis for the implementation of the MDGs both central and regional governments policies in Kuningan, needs analysis, feasibility studies and evaluation of the program targets.

\section{Input Evaluation}

The focus of the evaluation is the input source involved in assisting the achievement of program objectives. Evaluation of the input is an implementation of the evaluation context. After the identification of needs in the context of the evaluation and then an assessment of the ability to meet the needs that have diidentifikasi. The Process of the assessment is by designing programs to meet objectives. In the assessment process is to identify strategies that are most likely to achieve the desired result (Eseryel: 2002: 95). The design of the program by developing a program implementation plan and establish relevant strategies, test strategies to achieve the plan, by looking at the time of implementation, financing, potential that can be developed and possible obstacles to be faced. Then we determine the resources required, determine the resources available and adequate to implement the program. We can hire human resources by giving them a test or an exam so the decision was served input evaluation 
arrangement with projecting and analyzing the design of alternative procedures.

To implement the program we require some resources (material and human resources) and the other carrying capacity. Then the evaluation context focused on the evaluation of the carrying capacity of the implementation of the program. The goal is to understand how to utilize the input to achieve the objectives of the program. Input evaluation is an evaluation of a decision to serve the arrangement by providing information to assist decision makers and resource procedures for designing or selecting the appropriate method. Through the input evaluation will also provide information to look for alternative strategies and procedures appropriate to utilize the available resources and the process to set up and use resource decisions.

By comparing the input program to be conducted by another program, comparing the cost of the program with other programs in order to determine the cost-efficiency of activities and estimate its advantages and disadvantages. Understanding the result evaluations of the input will control the execution of the program for the right target and utilize the best resources to improve program implementation and to overcome the obstacles faced. So basically evaluating input includes planning procedures and costs that will be done to meet the demands and use the potential to meet the demands.

The core of the input evaluation is to determine the resources required. The main component of the input evaluation is the availability of human resources, facilities and supporting infrastructure, sources of financing, and procedures or rules that required a program. Based on the descriptions above may be concluded that the input evaluation is an evaluation to help organize a decision by way of projecting and analyzing the design of alternative procedures, work plan, create a strategy that will be done, set a budget and designing or selecting appropriate methods and materials.

On the MDGs, the input evaluation is done by evaluating the financing programs, the adequacy of human resources and infrastructure support (Zahda: 2005: 12).

\section{Process Evaluation}

Process Evaluation is conducted to know how the policy or program is implemented. The main focus in the evaluation of the implementation process of planning to achieve the goals and objectives of the program in order to obtain the information to control the execution of the program. Process Evaluation is the process of monitoring in implementing the program. Evaluation is done by controlling the established procedures, plans have been drawn up by taking into account the weaknesses and the conflicts that may occur during the program implemented. So that in the process evaluation we will produce the necessary information to determine whether the planned program will be accepted, modified or discontinued. This information is obtained by identifying the differences between implementations and standards implementation. Other than that, on the process evaluation it is noted how the executors of the program in conducting and the moral of the executors (Stufflebeam: 2003: 67). In brief 
evaluation of the process is an activities to evaluate the implementation of policies or program. To implement policies, it is required the factors that can support its success, that is, bureaucratic structure, resource, communication and disposition (Edwad III: 1986: 14). In the evaluation of the MDGs program evaluation is conducted with paying attention to these factors.

Process evaluation component in the CIPP did not mention the bureaucratic structure. According to the characteristics of the MDGs programs one of which is the involvement of the bureaucratic structure. Then the process evaluation of the MDGs is very needed to evaluate the involvement of the bureaucratic structure in reaching the goals of MDGs.

Against the bureaucratic structure, the evaluation is done by evaluating the response of the program executors in carrying out the activities, while for communication performed by an evaluation of the communication pattern, the frequency of communication and discussions to complete the activities. To reach out the success of any unit or the executor level should be given the disposition (authority) that is clear, so that the executor has their adapted steps to the state of the field but did not against the procedures and policies that have been set. For the evaluation of the process evaluation is focused on the weaknesses, response of program executors, conflict, communication patterns and evaluation disposition. The evaluation of focus will effective in giving assessments and decisions (Ho: 2011: 546). On the MDGs, the process evaluation is conducted by evaluating to: (1) the implementation of activities that include: administration, identification of problems encountered in the field and activities to follow up the findings of the problem, (2) monitoring the implementation of activities which include; implementation of visits, discussion of the monitoring team and the executors along with the evaluation about reportation of monitoring team, (3) evaluation of the disposition, and (4) control range bureaucratic structure. Evaluation of the control range bureaucratic structure is expected to improve communication patterns bureaucracy and government organizations (Haynes: 2008: 10). Furthermore from improvement of the good repair control range is creating good governance organization and impact on social improvement (Burstein: 1991: 330).

\section{Result Evaluation}

Result evaluation is the final part of the CIPP evaluation model. The main focus in the evaluation of the product is the result obtained after the program is completed by identifying and assessing the results of the project. Evaluation of the results of an evaluation of the present decision to determine the extent to which objectives that has been achieved and to determine the cause of the results obtained. At the evaluation stage of the product is done to see the achievement of the set objectives. The results that have been achieved are then compared to the criteria that has been specified in program planning. The main activity in the evaluation of the product is the depiction, the findings of the program and provide information for decision making.

Evaluation of the results described conformity with the results of planning, financing efficiency, measure effectiveness and can estimate the 
goodness and weaknesses so that the program can interpret Result Evaluations of its goals. In addition, the evaluation is expected to present the information to make decisions and are useful for providing policy alternatives that will be done (Mutrofin: 2010: 35). The results of the evaluation of the results is then used as a consideration to make recommendations sectoral improvements at each stage of the context evaluation, input, process and outcome, and in general can be used as a consideration of whether the MDGs must be stopped, repaired or improved. For effective recommendation should be set in a legal district product Based on the study of theory and MDGs program set its success criteria of the MDGs program in education as follow:

Tabel 1.Criteria of the evaluation of MDGs program in education at Kuningan Regency

\begin{tabular}{|l|l|}
\hline Evaluation & Succes Criteria \\
\hline \multirow{5}{*}{ Component } & 1. Purpose and legal basis, Kuningan Local Government \\
follow up the goal achievement of the MDGs through regional \\
policy and regional action plans have strong legal force \\
2. Analysis of needs, namely MDGs program in education \\
accordance with stakeholders and education experts \\
3. The terms of the implementation of the MDGs program in \\
education are fulfilled \\
4. Program goals, Kuningan local government MDGs \\
implementing the MDGs program in education at the sub- \\
districts with low HDI indication \\
\hline 1. Planning of the program is that the local that makes the \\
MDGs program continuously (Continuity of the MDGs \\
program 2011-2015) \\
2. Financing, namely local governments provide sufficient and \\
continuous funding for the implementation of the MDGs \\
program the \\
3. Guidelines for the implementation, the government makes \\
implementation guidelines implementative \\
4. Facilities and infrastructure, which is the fulfillment of \\
infrastructure standards that support the process of \\
implementation of the MDGs in education \\
5. HR, the local government gives the socialization to the \\
executors of HR of the MDGs program. \\
1. The implementation of the MDGs, namely activities carried \\
out a major contribution to the increasing in GER, NER \\
primary school and junior high school \\
2. Implementation of monitoring, the monitoring team visits, \\
provide direction, follow up and evaluate problems. \\
3. Socialization, explanation of MDGs program continuously \\
to the executors of MDGs activities in education to \\
understand and implement the MDGs development paradigm \\
4. Coordination, implementing the MDGs to coordinate \\
activities between units within and external to Satuan Kerja \\
Perangkat Daerah (SKPD). \\
1. The net enrollment ratio (NER), namely the achievement of \\
\hline
\end{tabular}




\begin{tabular}{|l|l|}
\hline $\begin{array}{l}\text { Evaluation } \\
\text { Component }\end{array}$ & Succes Criteria \\
\hline \multirow{2}{*}{ Result } & $\begin{array}{l}\text { the NER primary school and junior high school annually } \\
\text { appropriate with the target set }\end{array}$ \\
& $\begin{array}{l}\text { 2. Gross Enrolment Ratio (GER), namely the achievement of } \\
\text { GER primary school and junior high school annually } \\
\text { appropriate with the target set }\end{array}$ \\
\hline
\end{tabular}

\section{THEORETICAL STUDY}

Program evaluation is the systematic collection of data for the assessment and the decision of the program (Patton: 1997: 23). From the formula, there are three important things to evaluate that data collection, assessment and decision making. It is important to capture the data that the data collection should be carried out systematically in accordance with the evaluation design (Dale: 2004: 44). It can be interpreted that the data collection should have a plan in order to obtain the correct data. Systematic retrieval of data has an idea that should be adapted to the stages and procedures established in the planning process evaluation. Systematic retrieval of data that will give a true conception of the implementation of the program.

After a systematic process of data collection, the evaluation was followed-up by assessment. Assessment is done based on the facts obtained and granting criteria on objects (Djaali; 2008: 1). The assessment can be done by comparing the results of the achievement of the program with the goals set in program planning. The same thing was raised by Rutman that program evaluation is used to measure the extent to which program objectives achieved (Leonard: 1980: 19). Results of the assessment is then used as the basis for determining decisions. As stated by Mizikaci that evaluation is a systematic step through data collection to give consideration and decision (Mizikazi: 2006: 41).

The intended decision is a decision making for the program. The decision is made to repairs programs and policies that will come. (Patton: 1997). Thus the purpose of the evaluation is to improve policies and programs in the next period. This concurs with Spaulding who argued that evaluation is done for the purposes of decision making, determining the assessment of the program and make a recommendation (Mizikazi: 2006: 5).

\section{METHOD}

The study was conducted at the Local Government of West Java Kuningan Regency especially in BAPPEDA Office and the Department of Education held since June 2013 up to July 2014. The research is using evaluative study with a qualitative approach. Evaluation study was not intended to prove a hypothesis but it is intended to improve programs or policies pursued (Stufflebeam: 1984: 325). Program evaluation was conducted to know the achievements of stargets that have been set and then give a decision on the program. 
Context evaluation of the MDGs in education is the goal, the legal basis for program implementation, assessment of needs analysis, the adequacy of the terms of the program, and the goals. Context evaluation is conducted to know the suitability of the implementation of the MDGs goals at provincial level and and the implementation of the MDGs program in Kuningan Regency, knowing the follow-up of the legal basis and the central government policies on MDGs progam, knowing the need to support the assessment, feasibility study of the implementation of MDGs program, and the program goals.

Input evaluation in the program include the MDGs planning financing issued by the Kuningan local government for activities that support the achievement of the MDGs. Evaluation of financing to see how the continuous financing and professionally done by Kuningan local government during the implementation of the MDGs program. In addition to financing the input evaluation is done to look at the infrastructure that is used for the conduct of activities and team monitoring of the MDGs, knowing the implementation guidelines for the implementation activities of the MDGs and human resources prepared for implementing the MDGs program which is good in quality as well as in quantity of program executors and support infrastructure. The evaluation of the input is done to know the carrying capacity of Kuningan local government to achieve the goals of MDGs program. Process Evaluation is conducted to know the implementation of MDGs activities which include: (1) the implementation of activities consists of the implementation of MDGs by geographic approach and economic approach (2) the implementation of monitoring includes monitoring team visits, discussion of the monitoring team, reporting (3) socialization and (4) coordination. Product evaluation on MDGs in education program is conducted with reference to the achievement of elementary and junior high NER, GER of elementary and junior high school.

In accordance with theoretical studies that have been raised, CIPP model of an evaluation based on the component of context evaluation, input, process and product. Design of the study describes the groove on implementing evaluation at each component evaluation and describes the process of evaluation of each of these components. The study design is described as follow: 


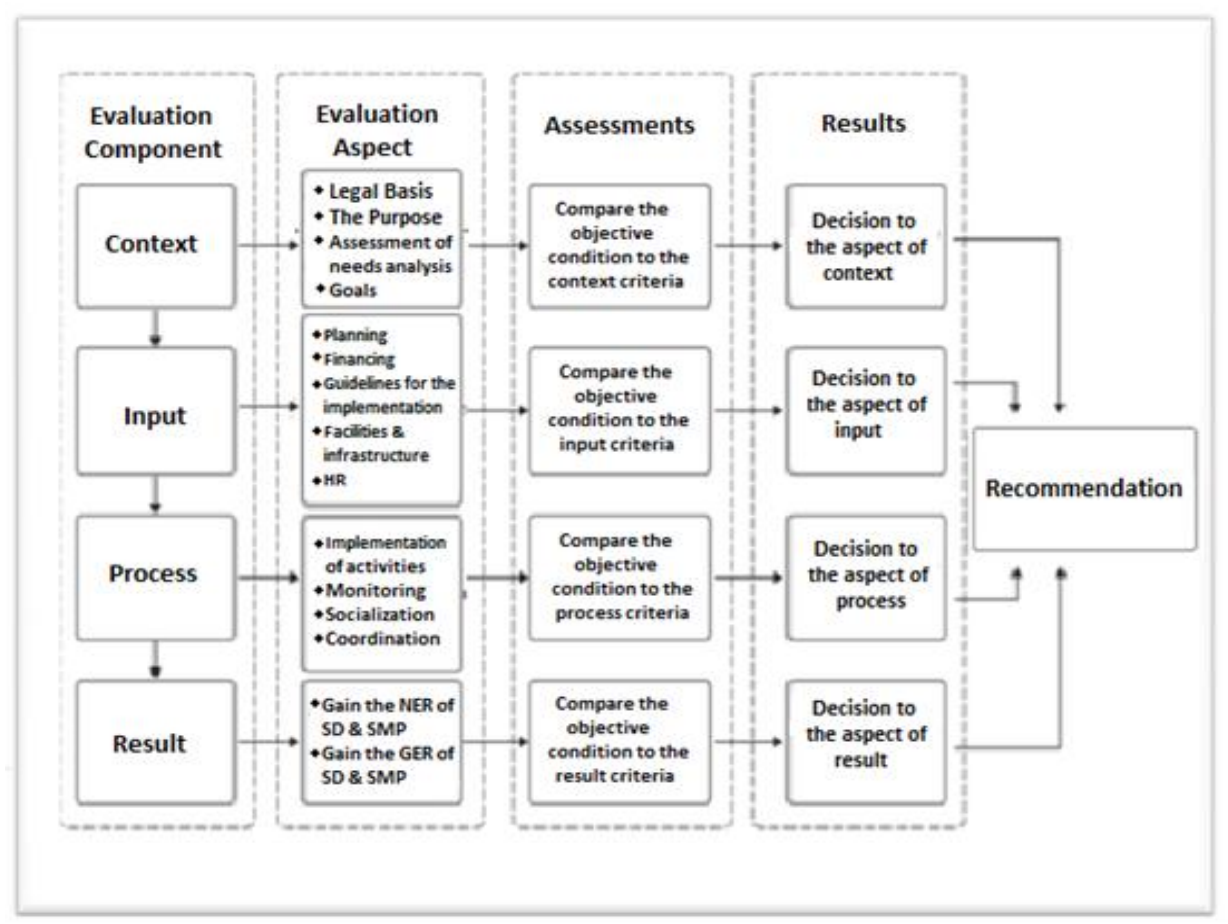

Picture.1 Evaluation Design of CIPP Model for the MDGs program in Education

The selected subject of the study is MDGs stakeholder in an environment of Kuningan District Government of West Java is Head of BAPPEDA, Dept. of Education, Head of Education Office of Program, MDGs Monitoring Team Member, Head of Government BAPPEDA, Head of the Legal of Kuningan Regional Secretariat. Head of BAPPEDA "key informants" in the study. Head of BAPPEDA is the person who know the most of the whole process of planning and the foundation of implementation of MDGs program. Through BAPPEDA head researchers studied the information about the planning, implementation, process, and output in MDGs program. In accordance with the qualitative research approach is done a triangulation to the informant in the Department of Education conducted with the snowball according to the information obtained. Head of the Legal has been the subject of research for the legality of the activities of the MDGs requires a strong legal and other informants in accordance with the findings in the field of information.

Besides informants of stakeholders, the subject of research is documents that relate to the MDGs in education. It is Kuningan Regency, a local action plan in the province of West Java in 2010, 2011, 2012, 2013, as the results of monitoring activities of MDGs and Local Regulation of Kuningan Regency No. 7 of 2009 about the Medium Term Development Plan of 2009-2013, Long Term Development Plan 2005-2025 Kuningan Regency, Education Profile of Kuningan Regency 2010 and 2013 and the Local Government Performance Reports. 
CIPP analized the data based on its evaluation component. The criteria of the evaluation refers to the credibility, triangulate, dependalibility, transferability and confirmability.

\section{RESULTS}

\section{Context Evaluation}

To follow-up the central government policies, Local Government of Kuningan Regency build up a team whose the task was to design a Regional Action Plan (RAD) the achievement of MDGs. Preparation of RAD adapted to local policies such as long-term development plan 2005-2025 Kuningan regency, a medium-term of five-year development plan and a common policy of budget. With these steps, the MDGs being a local development rumors and made as an indicator of the success of regional development.

To implement RAD in achievement of the MDGs of Local Government sets the guidelines through a decree of the Head of BAPPEDA. As a guideline implementation of MDGs, RAD load the stages of achieving the MDGs, the primary task of monitoring team of MDGs activities, programs and budget plan of MDGs program until 2015. In the implementation, the guidelines have less implementation and effort to make a practical steps in resolve problems in the field. In the purpose of local government's evaluation has followed-up the legal basis of the activities of the central government but has not been effective to guide it.

Based on the analysis of the needs, implementation of the MDGs programs in education are needed by the regional areas. It can be explained that the MDGs programs in education have a positive impact on development of regional areas such as (1) MDGs program spur regional areas to accelerate improvement of the quality of human resources through education, (2) the existence of the MDGs program is the right step to increase Human Development Index (HDI), (3) The construction of the MDGs promotes government development can be measured and clarify the target of 7-15 years learning opportunities and (4) the existence of the MDGs program has prompted the government to carry out the stages of development that is measurable and focused.

The picture explains that educations through MDGs program is needed and have a positive impact. Based on the results of the analysis of needs, the Kuningan Regency is include in the regional areas to get a positive influence on the MDGs programs in education, these results indicated by the increased of enrollment of citizens for completing their children's education up to nine years of basic education, increasing educational infrastructure development up to the border areas, presence of GER and NER stages increase every year and the guarantee of MDGs education activities funded by the local government through the APBD (budget).

Evaluation is done to see the readiness of the implementation of the program (Zahda: 2005: 2012). Kuningan Regency is included in regional areas with low level of Pendapatan Asli Daerah (PAD). When enrolling MDGs program in education most of the elementary school classroom are in 
severely damaged and lightly damaged condition and by the Kuningan's education profile data in 2011 has reached 3727 units. The condition is very difficult for local government to increase citizen participation in primary and secondary education, while for improving the condition of schools needs quite a large of local funds. The Limited local funds for development indicate that Kuningan is includes in areas with limited eligibility level in the implementation of MDGs in education.

To solve the condition the local government makes strategies to improve basic education services and facilitate access to educational services. The targets of these activities are regional areas that have a low HDI indication. The move comes on the grounds: (1) in these regional areas the continuing education to the level of junior high school are still relatively low and (2) in these regional areas economic levels of community are still low. The strategy made a good impact on the level of citizen participation in education is indicated by the increased participation of citizens in the 9-year basic education. Thus it can be said that the MDGs in education targets activities through geographic and economic approach is considered appropriate.

\section{Input evaluation}

The input evaluation is an evaluation to set the justification of budget, funds or other sources. (Frye: 2012: 288-299). To carry out MDGs activities in education Kuningan's local government makes RAD achievement of the MDGs. The RAD has been implemented in the regional area budget policy. Every year the local government prioritize the activities of the MDGs in education in the Anggaran Pendapatan dan Belanja Daerah (APBD) (regional budget revenue and expenditure (budget)). As a product of local law the APBD is a guarantee implementation of the MDGs in education ensured carried out by the Local Government reflected from the priority of activities in the regional budget.

The disadvantage is the consistency of the local government in allocating MDGs' activities budget. The budget allocation since the implementation of the MDGs by 2011 seems to fluctuate. The Inconsistency is understandable because the Kuningan Regency is included in regional areas with low PAD levels. It has an impact on the low level of independence and the degree of dependence on its central authority's aid is very high. For that it is necessary to perform activities that can increase PAD to support the MDGs.

To support the implementation of the MDGs programs guidelines and technical guidelines for the implementation of activities is required. Technical guidelines are needed as a guide for program implementation, coordination guidelines and guidelines for the organization in the implementation of the MDGs in education but Kuningan's local government has not made the implementation guidelines and the technical guidelines. For implementation guidelines for implementing the MDGs in education is using the implementation guidelines from the Department of Education as the lead sector implementation of the MDGs in education. This is an obstacle in the 
implementation of the MDGs for it is a lack of clear guidelines in coordination, evaluation and follow-up problems found in the field.

Other thing to support the implementation of the MDGs is the fulfillment of the MDGs' implementation infrastructure and monitoring team. For implementing the MDGs the infrastructure used by the executor is the infrastructure in the Department of Education. This is a local government policy that the infrastructure used in the implementation of the MDGs are the existing facilities in Satuan Kerja Perangkat Daerah (SKPD) respectively and the local government did not provide the means for implementing the MDGs program including infrastructure monitoring team. It has an impact on the implementation of the MDGs monitoring that are not carried out optimally because there is no adequate infrastructure and support financial operations.

\section{Process Evaluation}

The Process evaluation is the process of monitoring the implementation of the program (Zhang: 2011: 57). The results of monitoring the implementation of the program, there are three main activities undertaken by Kuningan local government to improve basic education NER and GER is Program dan Percepatan Pembangunan Infrastruktur Pendidikan (PDPPIP), The development of Primary School to Junior High School under one roof and distribution of school operational assistance.

The DPPIP program is an excellent program by Kuningan local government to improve services and to shift the access to education closer to citizens. The program was concluded as a quite significant program in improving NER and GER. The success of the DPPIP program is indicated by the increasing number of IPM in areas that get DPPIP program. Since the 2011-2013 DPPIP greater funding comes from a Dana Alokasi Khusus (DAK) in education given by the central government to the region.

Another program is the implementation of primary school to junior high school under one roof in areas with poor access to education. These measures were taken by the government to bring closer the public access to schools, especially Junior High School. The goal is citizens that geographically have less access to education services.

The steps taken by the government give an overview of the efforts from the government in the implementation of the MDGs in education.

Other activities include the Bantuan Operasional Sekolah (BOS) is given to students from poor families. The effort is the central government step to provide a solution to the poor with children aged 7-15 years who can not afford to elementary and junior high school levels. The local's role is to provide the contribution right on the target. The move is an effort to achieve the MDGs through economic approach.

In addition to the implementation of the activities supporting the implementation of the MDGs in the field of education is the response of activities executors. Another important point is the response of activities executors shown by the activities executors efforts to understand and implement the understanding to the activities of MDGs in education. The efforts made by MDGs activities executors to understand the paradigm of the 
MDGs are still considered less one reason is the lack of socialization of the MDGs to the activities executors.

\section{Result Evaluation}

The Result evaluation are evaluation that conducted to measure the achievement of the program's success. Result Evaluation include two indicators of educational achievement of the MDGs, namely achievement of GER and NER for primary school and junior high school.

Measurement is done by comparing the achievements of NER and GER for primary school ang junior high school with the target set at Rencana Aksi Daerah (RAD) implementation of the MDGs (BAPPEDA Kuningan: 2012: 3-9). Since the MDGs program implemented in 2011 to 2013 NER and GER showed pretty good improvement. This current statement appropriate in accordance to educational profile data of Kuningan Regency in 2011 GER of primary school at $103.37 \%$ and GER of junior high school at $98.84 \%$, NER of primary school $99.78 \%$ and NER of junior high school at $90.52 \%$. The increase is largely due to the increase in educational services in the Kuningan Regency through improvement in infrastructures means at primary school and junior high school through out rural and regional levels of the regional border. In addition to the improvement of facilities and infrastructure of primary school and junior high school local authorities also make improvements in rural infrastructure which provides the impact of increased access to transportation from villages to cities.

\section{DISCUSSION}

The findings in the context of the evaluation focused on four aspects of the evaluation, namely: (1) the purpose and legal basis, (2) analysis of requirements, (3) establish the feasibility study on the evaluation of the decision being actualization and (4) the target with ideal categories. Aspects that need to be improved are the aspect of the legal basis implementation of the MDGs. The legal basis implementation used for the implementation of the MDGs is a RAD achievement of the MDGs established by Surat Keputusan (SK) (Decree) by Head of BAPPEDA (Planning Agency).

MDGs is a policies and national programs and has been an issue of national development paradigm. To achieve the MDGs the government has issued policies that can be used by local authorities in the implementation of programs in the regional areas. The central government stipulates that the head of the provincial-level MDG implementation team was the governor. The provision is in accordance with the guidelines for national action plans that the governor will be responsible for the implementation of the MDGs programs. The strategy is carried out in order for the MDGs programs indirectly become the regional areas' priority program and gain political support from the chief of the regional area.

Political support is needed in the implementation of the MDGs in view of the overall activity of the MDGs into the activities of local government established by the APBD. APBD is a legal product between the local government by local Regional House of Representative as a political 
institution that represents the community. In preparing the APBD, local Regional House of Representative has an important role in the planning, establishment and evaluation of the implementation of the APBD. Thus the determination of the activities of the MDGs in the budget is in dire need of political support from the district head of the regional area and the local Regional House of Representative.

Determination of the implementation team responsible for MDGs in regional level by the Head of Bappeda becomes less strategic for two reasons: (1) Head of Bappeda does not have power enough by the local Regional House of Representative in the preparation of MDG programs in the APBD and (2) Head of Bappeda also does not have the political budget power enough to plan, control and evaluate the implementation of programs of the MDGs. Such circumstances become a weakness in the implementation of programs of the MDGs in Kuningan Regency.

To improve the implementation of the MDGs in aspect of policies can be done by setting the RAD and guidelines for the implementation of the MDGs in Kuningan Regency through the Bupati's regulation. The Bupati's regulation have the force of law higher than Head of Bapeda's decree. The regulation has the setting properties and has the power to top-down activity executor. The strategic value of the regulation can provide position to MDGs as a program that should be implemented and have a strategic value in improving development outcomes.

Proposal for guidelines of the implementation of MDGs has been submitted by BAPPEDA into the Bupati's regulation on the grounds of MDGs becomes development issues and its achievements to be the standard for judging the success of the regional area. However, the proposal has not been realized with the following considerations: (1) there are activities that are considered to be equivalent to the MDGs that allows requesting equality in the implementation and regulation through laws, (2) to be guidelines for the implementation of the MDGs into local products are still required conformity with the relevant laws for example, the long-term development plan, the medium-term development plan that requires synchronization with MDGs programs and (3) the implementation of the MDGs can be overcome by making activities as a priority of area development.

The Bupati's regulation has the advantage to increase the force of law and policy in implementing the MDGs' achievement: (1) the regulation is binding in implementation. Budgetary discipline and discipline of the continued implementation of MDGs program requires consistency attitudes by the policy makers and local policy implementers. Consistency can be done by creating a rule that can be a reference in the implementation of government activities, (2) the political support of the Bupati and the local Regional House of Representative. Through the regulation, it will politically make the MDGs as a political commitment shared between the Bupati and the local Regional House of Representative because the regulation will be local regulation product and may become the legal basis for the activities that support the implementation of the MDGs and (3) the regulation would be more having the power of co-ordination with Heads of Departments who 
are implementing the MDGs activities. Coordination is needed considering the implementation of MDGs is done by several fields of executor.

Discussion of the results of input evaluation focused on several aspects, namely: (1) funding, (2) guidelines for the implementation, (3) infrastructure and (4) human resources. Research findings related to the financing is less consistency in financing for the funds derived from the DAK for the implementation of the MDGs in education, especially for the improvement of school facilities and infrastructure. The amount of funding for the implementation of the MDGs in education during the years 2011, 2012 and 2013 are vary and showed a decline. The decline is due to changes in development priorities that lead to changes in budget allocation. DAK numeral reduction for MDGs in the regional areas has considerable influence considering Kuningan Regency includes in regional areas that has a low PAD.

The low level of independence will give effect to the difficulty of the regional areas to make adjustments to programs made by the central government since other than the regional area must conform with the central government's programs but it also had to adjust to programs that has been ongoing and has been established earlier for example Rencana Pembangunan Jangka Menengah (RPJMD) and Rencana Pembangunan Jangka Panjang (RPJP). The adjustment will experience enough difficulties caused by: (1) the difference between the central government development priorities and local government within the medium term (5 years), (2) the strength between the central and local product of laws. MDGs programs is the product of policy that evenly applied nationally while in the regional areas when MDGs made as a regional development paradigm already has an obligation to implement development programs that has been established by local regulations and (3) the political aspect that the head region will prioritize programs in accordance with the vision and mission of the regent / vice regent compared with the MDGs. The three causes for the regional areas having a low level of independence gives enough influence to the political policy budgetary implicating the allocation of the MDGs.

Such circumstances can be understood that ultimately Kuningan Local Government relies heavily on the central government in the implementation of programs of the MDGs. It is very visible from the percentage of improvement activities of education infrastructure through DPPIP programs the largest funding source is always from the central government through the DAK education field.

The results of the evaluation obtained several findings: (1) implementation of the MDGs, namely DPPIP and BOS activities, (2) monitoring and (3) the support of bureaucratic structure. The finding is based on the results of the assessment of the data obtained and carefully studied to better understand the actual condition.

The first finding, the implementation of DPPIP aspect which is still less is the aspect of input. Input in question is the amount of funds provided for the implementation of the program. DPPIP activity is activities that since the beginning of the implementation of the MDGs become highly prioritized activities to achieve the MDGs in education. DPPIP activity aims to increase 
the capacity of schools to accommodate learners to build new classrooms and improve the schools states that were severely and lightly damaged before.

For the implementation of DPPIP requires huge funds. DPPIP funding needs for the year 2011-2013 are largely sourced from DAK education. Many needs for school construction and repair of new classes makes the needs of DPPIP activities becomes huge, but because of the limitation in ability of the area the input funds for the implementation of DPPIP activities are considered insufficient. Another finding is the implementation of the monitoring activity that runs less than optimal. Implementation of monitoring is needed to conduct a formative evaluation of the implementation of the activities of the MDGs in education. Results of interviews and documentation obtained the explanation that the monitoring team for the activities of the MDGs is not getting enough facilities for monitoring. Facilities used by the monitoring team are existing facilities in each activity executor Satuan Kerja Perangkat Daerah (SKPD). In the implementation those facilities are more use to the benefit each of SKPD.

In addition to the lack of getting the facility monitoring team also did not get the support for the implementation of monitoring. The study documentation is not in the budget there is no budget allocation for the implementation of the MDGs monitoring activities. Ideally, according to the workload of the monitoring team is given sufficient funds to carry out the monitoring.

Increased NER of primary school until 2013 according to the Badan Pusat Statistika (BPS) Kuningan Regency reached $103.37 \%$ and were the success of the MDGs in education. This figure can be given a meaning that non-formal education conducted successfully increased the public participation and to realize the importance of basic education. Growing public awareness of the educational became one of the goals in development because through education is expected to change the mindset and the attitude of community. Thus the implementation of the MDGs in education is one of the government programs that can change communities in Kuningan Regency to a better life. Indicators of community improvement are shown by the rising Human Development Index (HDI) which increased in Kuningan Regency and reflects the improvement in the economic, health and education sectors.

\section{CONCLUSION}

Implementation of the MDGs programs in education in the Kuningan Regency has not been supported by RAD which has a strong force of law, financing programs still rely on financial support from the central government and the provinces, still lack of infrastructure support for the monitoring team, lack of socialization and coordination among program executor. In addition the MDGs program has had an impact on the improvement of educational services in elementary and junior high school levels as indicated by the increase in NER and GER at primary school and junior high school levels. 
To improve the MDGs in the regional area it is recommended that RAD established through the Bupati's regulation, increasing the cost of local assistance for MDGs activities, conduct intensive socialization to activities executors and improve coordination between the program executor units. In addition to improve the efficiency of the MDGs program it is needed to improves public perceptions of education through awareness and increases education understanding of the community through religious and cultural approach.

\section{RECOMMENDATION}

1. The spirit and values of the MDGs in education for the liberate children aged 7-15 years to the completion of basic education can be the spirit of the regional area to continue to improve the quality of community through education. To ensure the sustainability of the program local government can make some important issues in the MDGs as part of a regional issue for policy analysis and policy implementation. The strategic steps can be done by making the issue of MDGs in education became a part of the general policy of the local government budget.

2. To improve the implementation of the MDGs in education the guidelines for the implementation and working procedures ought to be established by the Bupati's regulation. Legal provisions become urgent to facilitate decision making and improve the program bargaining position in the regional budget planning. The legal provisions will enough be the basis for budget policy making to make the MDGs in education as a program that needs to be improved in quality and in the delivery of its programs. The Effect to be expected is the growing public awareness to fully increase their participation in improving the quality of the children's future. Through the MDGs education program has provided a stimulus for people to send their children to school as proven by the increase in NER and GER.

3. To increase the quality of implementation there should be clear and binding guidelines to improve coordination between units in a bureaucratic structure. The importance of coordination in the implementation of the MDGs in education can at least be done by the education department, agency of Ciptakarya, board of education, and local universities. Coordination among these stakeholders will provide a more accurate recommendation since the planning, implementation and ending evaluation of activities.

4. To maintain the direction and goals of the MDGs in education to match the expected target can be aided by an effective implementation of monitoring. Monitoring team should be established by the Bupati and gain the support facilities and monitoring funds. The success of monitoring in the activities of the MDGs is the basis for improving the implementation of the program both at the time of implementation and improvement of programs for the next period.

5. Other efforts to improve the implementation of the MDGs in education are the cultural and religious approach. The approach is expected to change the community's mindset and perception of the importance of education. The existence of cultural and religious approach will be one of the factors that 
can explain the public perception of the importance of education, a change of mindset, and behavior. Success in changing the perception through religious and cultural approach can be a substantial capital to create conscious community education.

6. To find out more about the MDGs program in education so that there will be further research on MDGs program in education for disability community.

\section{REFERENCES}

Azizi Yahaya "The Using of Model Input, Process and Product (CIPP) in Learning Programs Assessment," International Conference on Challenges and Prospect in Teacher Education (16-17 Juli 2001).

Boulmetis dan Dutwin dalam Hatice Sancar Tokmak, Meltem Baturay dan Peter F. Adde, "Applying the Context, Input, Process, Product Evaluation Model for Evaluation, research, and Redesign of an Onine Master's Program," Journal Athabasca Unversity, Vol. 14 (93), 2013, hh. 1-15.

Burstein, Paul. "Policy Domain: Organization, Culture dan Policy Outcomes." Annual Review of Sociology, Vol. 17 (JSTOR), 1991, hh. 325-335.

Dale, Reider. Evaluating Development Program and Project. New Delhi: Sage Publications, 2004.

Demarteu, Michael. "A Theoritical Frame and Grid for Analysis of Programe Evaluation Practices." Journal of Evaluation, Vol. 8 (4), 2002, hh. 452463.

Djaali dan Pudji Muljono. Pengukuran dalam Bidang Pendidikan. Jakarta: PT Gramedia, 2008.

Dunn, Wiliam. Public Policy, terjemahan Muhadjir Darwin. Yogyakarta: PT. Hanindita Graha Widia, 2001.

Edward III, George C. Implementing Public Policy. Washington, D.C: Conggressional Querterly Press, 1980.

Eseryel, Deniz. "Approaches to Evaluation of Training: Theory and Practice." Educational Technology and Society, ” Vol. 5 (2), 2002, hh. 1-9.

Frye, Ann W., dan Paul A. Hemmer. "Program Evaluation Models and Related Theories: AMEE Guide." Medical Teacher, Vol. 34 (67), 2012, hh. 288-299.

Guba, Egon G. dan Yvonna S. Lincoln. Effective Evaluation. California: JosseyBass Publisher, 1983. 
Kuo, Lung Hsing. “An Evaluation Model of Integrating Emerging Technology into Formal Curriculum." International Journal of Education and Information Technologies, Vol. 3 (6), 2012, hh. 250-259.

Leonard, Rutman. Planning Useful Evaluation. California: Sage Publications Inc., 1980.

Mizikazi, Fatma. "A Systems Appluation to Progam Evaluation Model for Quality in Higher Education." Quality Assurance in Education, Vol. 14 (1), 2006, hh. 36-44.

Usmani, Mohammad Abdul Wahid dan Suraiya Khatoon. "Meta Evaluation of a Teacher Evaluation Programme Using CIPP Model." Archives Des Sciences, Vol. 66 (7), 2012, hh. 230-252.

Mutrofin. Evaluasi Program Untuk Pemula. Yogyakarta: LaksBang Pressindo, 2010.

Nugroho, Riant. Kebijakan Publik Formulasi, Implementasi dan Evaluasi. Jakarta: PT Gramedia, 2004. . Kebijakan Pendidikan. Yogyakarta: Pustaka Pelajar, 2008.

Owen, John M. Program Evaluation Form and Approach. Crown Nest, NSW: Midlands Typesetters, 2006.

Parsons, Warnye. Public Policy Pengantar Teori dan Praktik Analisis Kebijakan, terjemahan Tri Wibowo Budi. Jakarta: Prenada Media Group, 2008.

Patton, Michael Quin. Utilization Focused Evaluation. California: Sage Publications, Inc., 1997.

Rossi, Peter H dan Howard E. Freeman. Evaluation: A Systemic Approach. California: Sage Publications Inc., 1985.

Royse, David, et al. Program Evaluation an Introduction. Toronto: Thomson Brooks, 2006.

Strauss, Anselm dan Juliet Corbin. Basic of Qualitative Research. California: Sage Publications Inc., 1990.

Stufflebeam, Daniel L., dan Anthony J. Shinkfield. Systematic Evaluation. Massachusetts: Klulwer-Nijhoff Publishing, 1984. . The Personal Evaluation Standars. California: Sage Publications Inc., 1988. 
Stufflebeam, Daniel L. The In CIPP Model for Evaluation. Boston: Kluwer Academic Publishers, 2000.

. "CIPP Evaluation Model Cheklist," http: //www.wmich.edu/ evalctr/checklists (diakses 10 Oktober 2013).

Sudjiono, Anas. Pengantar Evaluasi Pendidikan. Jakarta: PT Raja Grafindo Persada, 1996.

Tiantong, Monchai. "A Multiple Intelligences Supported Web-based Collaborative Learning Model Using Stufflebeam's CIPP Evaluation Model." International Journal of Humanities and Social Science, Vol. 3 (7), 2013, hh. 157-165.

Tseng, Kuo-Hung, et al. "Using the Context, Input, Process and Product Model to Asses an Enginering Curricullum." Word Transaction on Engineering and Technology Education, Vol. 8 (3), 2010, hh. 256-270.

Weis, Carol H. Evaluation Research. New Jersey: Prentice -Hall, 1972.

Yahaya, Azizi. "The Using of Model Context, Input, Process and Product (CIPP) in Learning Program Asessment," International Conference on Challanges and Prospect in Teacher Education, Universitas Teknologi Malaysia, Juli 2001.

Zahda, Joseph. Globalisation, Education and Policy Changing Paradigms. Dordrecht: Springer, 2005.

Zhang, Guili. "Using the Contexs, Input, Process and Product Evaluation Model (CIPP) as a Comprehensive Framework to Guide the Plannig, Implementation and Assesment of Service-learning Program." Journal of Higher Education Outreach and Engagement, Vol. 15 (4), 2011, hh. 54-65. 